Article

\title{
Biophysical Economics for Policy and Teaching: Mexico as an Example
}

\author{
Salvador Peniche Camps ${ }^{1, *}$, Charles A. S. Hall ${ }^{2}$ and Kent Klitgaard ${ }^{3}$ \\ 1 Departamento de Economía, Centro Universitario de Ciencias Económico Administrativas, Universidad de \\ Guadalajara, 45180 Guadalajara, Mexico \\ 2 Program in Environmental Science, College of Environmental Science and Forestry, State University of New \\ York, Syracuse, NY 13244, USA; chall@esf.edu \\ 3 Department of Economics, Wells College, Aurora, NY 13026, USA; kentk@wells.edu \\ * Correspondence: speniche@cucea.udg.mx or peniche@hotmail.com
}

Received: 31 January 2020; Accepted: 15 March 2020; Published: 25 March 2020

check for updates

\begin{abstract}
Many parts of the world are currently facing unprecedented social turmoil. Few understand that most of these "exploding" situations have a biophysical basis in patterns of consumption and the ratio of number of humans to resources available. Most "solutions" proposed are political oppression or, for the lucky, economic development, usually led by conventional economists. However, we believe that, for many regions, conventional economics, certainly alone and perhaps in their entirety, are not up to the job of addressing these crises. We propose a new discipline, Biophysical Economics, that addresses these lacunae and offers a good set of procedures for bringing much more natural science to the discipline of economics. This approach provides a stronger basis for training young people in both economics and heterodox political economy. We will need economists with this new training for a future that appears very different from today. This article outlines the rationales for further developing and teaching Biophysical Economics to demonstrate its utility and applies this economic lens to the economy of Mexico. We finish by providing an example of how a Biophysical Economics curriculum appropriate to analyzing and addressing the Mexican economic context might be developed and taught at the University of Guadalajara. This curriculum could also be adapted to other national, educational and institutional settings.
\end{abstract}

Keywords: biophysical economics; Mexico; education; transdiscipline

\section{Introduction: Contemporary Economic Crises Demonstrate the Need for a Biophysical Approach to Economics}

\subsection{Global Economic Crises and Their Biophysical Roots}

The world, and much of Latin America in particular, is facing a new suite of economic, environmental and social issues (including the COVID-19) that are proving to be quite resistant to traditional economic approaches and solutions. Yet they are critical to all issues of sustainability, be they social, political, economic or environmental. Some of the most obvious words to describe what is happening are increasing social chaos and collapse of governance. A more cryptic but possibly greater threat appears to be climate change and the inability of governments to do much about it. While the situation is most fully written about in the United Kingdom and the United States, it is certainly obvious also in Greece, France, Syria, Egypt, Iran and Nigeria, and, in Latin America, most acutely in Venezuela but also in Argentina, Ecuador, Colombia, Bolivia, Chile, Peru, Haiti and Brazil, as is reported by the news media every day [1-5]. Whereas in the United States and the UK, the most obvious causative agents are ever fiercer political divisions and erratic leadership, we see a more general pattern of long-predicted resource limitations that underlie much of the turmoil that is occurring. 
However, this resource-based perspective is much less understood or written about by reporters, political commentators and average citizens.

If we are correct in this analysis, the typical ways that we approach the world's sustainability issues (usually "economic") are unlikely to work and in fact are likely to be counterproductive. Even well-meaning "green solutions" that have been put forth, and with which we agree in principle, are often woefully lacking in any analytic base that would allow for their effective assessment or implementation, should that be possible.

What seems to be missing from the general and public discussion is an understanding of the changing relations between the number of people and the resources that are required to generate economic and social wellbeing, in other words a biophysical perspective. Many of the problems ensuing in the countries listed above, and elsewhere, are consistent with discussions and predictions that were made a half-century earlier and that can be summarized as "limits to growth". In the ensuing years since these predictions were made, the world's population has more than doubled, from about 3.7 billion in 1970 to approximately 7.7 billion in 2019. Economic aspirations have increased, and the resource base of many regions has been depleted, transferred abroad through various economic arrangements and debt structures, or seriously compromised.

While the long-predicted point of "peak oil" production may or may not have occurred for the world as a whole, it has clearly occurred for important South American oil producers including Argentina, on-shore Brazil, Colombia, Ecuador, Trinidad and Tobago and Venezuela [6-10]. More generally, there are many signs that resources, and especially resources per capita, are falling for many individual nations globally. For example, with regard to energy, Hallock et al. [11] found that peak oil had in fact occurred for some 38 of the world's 46 most important oil-producing nations. Mushalik [12] finds that peak oil has occurred for six of eight continents (Africa, Australia, Asia, Europe and South and Central America, including Mexico, with only North American "shale" and "tar sands", the Middle East and (ambiguously) Russia remaining as non-peak-oil regions. However, this critically important issue is not remarked upon by anyone beyond a few petroleum analysts [6-10].

When a nation hits peak oil production followed by decline, social chaos tends to follow. Riots in France were triggered by increases in gasoline prices, in Egypt and Ecuador by increases in subway fares, in Colombia by the removal of subsidies for gasoline and so on. More generally, as with peak oil in Algeria (which supplies France), Ecuador, Venezuela, Argentina and other nations, governments can no longer afford to subsidize gasoline, and workers feel the rug being pulled out from under them. This is happening all around the world. Political turmoil is interpreted by traditional political science and economics as a reaction of the poor to economic policies. Mainstream social sciences give virtually no importance to the fact that at the root of much of the social unrest lies the exhaustion of the material base of wealth.

The linkage between the growth, peak and decline of oil production for various individual countries and its subsequent political and economic chaos has been extremely well developed for many nations by Nafeez Ahmed in his aptly named book: Failing States, Collapsing Systems: Biophysical Triggers of Political Violence [13]. For most of the countries listed above Ahmed shows how, in earlier decades, increasing oil production and exports gave a new sense of prosperity to oil-producing nations and their governments, and made it possible for governments (even corrupt governments) to generate pensions, public transport, roads and other social amenities that gave the public a sense of improving social and economic conditions, sometimes even including the poor. Under these conditions, people often had more children, which were often well accommodated under the improving economic conditions [14]. However, when peak oil was reached, and especially when exports were no longer possible, both governments and economies in general faltered, dissatisfaction with governments increased, and social chaos and sometimes wars ensued. These trends are laid out very clearly for Syria, Egypt, Venezuela and elsewhere in Ahmed's book, and clearly apply to Mexico, Argentina and the UK as well. 
The objective of this research is to explore the possibility of incorporating the biophysical perspective in the economics curriculum, with the objective of promoting the training of specialists in economy with the knowledge and skills to solve the problems derived from the impacts of economic development on the environment.

The contribution of the study consists in presenting a specific case study, based on real socioeconomic needs, for the implementation of a model of incorporation of the biophysical perspective in the economics curriculum. In the future, this effort could work as a model of academic reform in the economics discipline throughout the country.

The consideration of the case of Mexico is relevant for at least two reasons: a) Mexico is a country with large natural reserves and important development perspectives. The country is at a very important moment in its history. With the advent of the new democratic government, a process of structural reform has begun; $b$ ) Because Mexico is a leading country in Latin America, Mexican success can drive academic reforms throughout the subcontinent.

\subsection{The Disjuncture between the Field of Economics and the Need to Address Biophysically-Based Economic Crises}

One might think that these tumultuous trends would be assessed by economists, as the situation manifests mostly as economic phenomena. However, the study of economics, which was rather diverse a century ago and often focused on concepts like "where do wealth and value come from?", had become increasingly homogenized under the rubric of neoclassical or market-oriented economics, which focuses instead on "how do markets generate prices which reflect relative scarcities and maximize satisfaction?" Understanding these changes in economic thought and practice is essential to understanding both the current disjuncture between the field of economics and the pressing need to address economic consequences of biophysical limits.

From the middle of the 18th century until the end of the 19th, classical political economists believed that value was created in the process of production. Most English-speaking economists thought that labor was the primary creator of value, although the earlier French Physiocrats believed that all new value was created by land and agricultural labor [15].

In the 1870s, economists in England, Switzerland and Austria replaced this objective theory of value with a subjective one. Value now depended upon how much a consumer was willing to pay, and this depended on marginal utility or how much a buyer thought another unit of the good or service was worth to him or her. In the 1890s, neoclassical economics was born as the theory of production was put on a marginal utility basis, known as marginal productivity, and a sense that the economy was more or less self-regulating. Neoclassical economics was dominant until the 1930s, when its theory of the self-regulating economy could not withstand the depths of the Great Depression. A new approach on the general behavior of the economy was needed, and in particular a new theory of growth and cycles.

In 1936 British economist John Maynard Keynes penned the General Theory of Employment, Interest and Money [16] which soon became the standard text for economic policies focusing on greater governmental intervention. In 1948, Paul Samuelson [17] integrated Keynesian policies within the framework of neoclassical economics in the "grand neoclassical synthesis": governments" use of spending and taxing, along with manipulation of the money supply and interest rates, was supposed to keep the economy in steady-state growth. However, in the early 1970s, Keynesian economics lost its luster. That theory could not explain the simultaneous inflation and recession that occurred in the wake of oil price spikes of that decade. Nor did it have answers for the collapse of the international monetary order or the peak in US oil production. For mainstream economics the end of the gold exchange standard, which was developed in 1944 at the International Monetary Convention, and the detachment of natural resources and energy prices from the real economy was a natural step to a free market and a globalized economy [18]. 
Thus, the profession returned to its earlier, more conservative vision of how the economy worked. In the battle for the minds of academia, pre-Keynesian neoclassical economics won the war with Keynesians, as well as with those who believed in limits to growth. In a way, this triumph is curious because those who understood limits to growth had a ready explanation for the simultaneous inflation (the ratio of money to energy had increased) and recession (the increased cost of energy sucked capital and spending away from the general economy, as explained in [19]).

With the traditional tools and theories, mainstream economics cannot explain these new developments, new situations that have emerged with global processes and technologies related to the traditional fields of economic analysis but also with the exhaustion of the natural base of development.

We believe that the time has come for a vigorous restructuring of economics to tackle the new realities of much of the world. Without acknowledging and dealing with basic biophysical/resource issues, or the social chaos discussed above, any kind of sustainability cannot possibly be developed. We are particularly concerned about the teaching of economics. The economics taught routinely in colleges and universities in both Mexico and the United States, the home countries of the authors, and indeed in countries around the world, is almost exclusively neoclassical economics (sometimes known as free market-oriented). Why this should be true is beyond our comprehension, for there are plenty of very serious, even devastating, critiques of conventional economics from within the discipline, e.g., $[19,20]$, not to mention the sophisticated critiques of the political left, and the serious critiques from ecological and especially Biophysical Economists, e.g., Hall and Klitgaard [21], Martinez and Rocca [22], Pengue [23] and LaTouche [24].

Many of the criticisms focus on the neoclassic basic assumption that economics should be a social science, based on satisfying the perceptions of individual wellbeing through how an individual chooses to allocate his or her money in "free" markets. Little or no mention is made of the need for raw materials and energy derived from nature to satisfy these needs, nor the social and environmental impacts necessarily generated by the process.

Far more comprehensive summaries of our criticism of conventional economics than we could present here can be found in [25] and especially [26], but suffice to say that, since the meaning of economics to most people is concrete, practical, and tightly linked to the biophysical world (e.g., a roof over their heads, food on the table, a car in the garage and fuel to run it), all of which live in the reality of the material world. We believe that economics as a discipline should not be only a social science, as is the case with conventional economics today, but be based on the natural sciences as well, since actual economies takes place in the real world where physical and biological laws prevail. Biophysical Economics represents a system of economics built upon the natural sciences as a base and integrated with the social sciences. It starts with the reality that all economic goods and services start with materials and energy taken by humans from the Earth. These raw materials are transformed into increasingly useful products through the application of energy (including human labor) within economies. Biophysical Economics usually pays less attention to satisfying unmeasurable and subjective individual wants and needs than mainstream economics does. Rather, it takes actual economic systems as they exist and quantifies the energy and materials associated with the actual money flows. For example, in the United States an average of about 6 Mega Joules of energy (roughly half a coffee cup of oil) is required to generate the goods and services associated with each one dollar of economic production (e.g., GDP). In addition, about half a pound of $\mathrm{CO}_{2}$ is associated with each dollar's worth of production (or spending). There are much more comprehensive descriptions found in $[27,28]$ and especially [21]. 
For students, one of the main benefits of learning Biophysical Economics is that it dovetails with what they are learning in their classes in natural science, whereas conventional economics generally seems divorced from, or inconsistent with, what they are learning in their classes in physics, chemistry, geology and biology, if they are taking them, which they should. Most importantly, Biophysical Economics does not break the laws of physics, as is the case with conventional neoclassical economics [29].

In order to understand Biophysical Economics and its relation to sustainability and sustainability teaching we focus on the economy of Mexico, a country that in many ways serves as a poster child for the need for and potential benefits of a biophysical approach to economics and teaching.

The proposal to incorporate the ecological perspective in the economics discipline was made based on the teaching experience of the authors. The selection of the case study was made based on the opportunity presented by the current situation in which the university authorities of the second most important University in the country, the University of Guadalajara, have been sensitized about the importance of this opportunity, for the economics discipline, for graduates and for the future of sustainability in the region.

Initially, a diagnosis of the areas of economic sciences is presented where the biophysical issue is essential to resolve the negative impacts of the economy on the environment. In this exercise, emphasis is placed on the complex and holistic nature of sustainability processes.

The proposal concludes with recommendations for the implementation of a biophysical economics curriculum for the Economics Degree at the University of Guadalajara.

\section{The Mexican Economy}

The incorporation of the biophysical perspective in the economics curriculum is based on a detailed analysis of the elements of the socio-environmental system that allows the existence of human society on the planet. The elements and relationships that characterize each particular society vary according to their historical evolution and their cultural and environmental particularities. The Mexican case presents a series of important particularities.

Mexico is entering into some very new problems and opportunities with respect to its economic and social circumstances. These are mostly biophysically induced, and include:

(1) Peak oil, long predicted, occurred in 2003 so that by 2019 production had declined by about half. While it is possible to extract more oil, the easy oil, along with the opportunities for exports and their revenues, are largely gone.

(2) The Mexican economy depends greatly on the US economy. Nearly $60 \%$ of foreign trade and $40 \%$ of foreign direct and indirect investment originate in the United States.

(3) Mexico increasingly has become a conduit for desperate and disaffected families from Central America seeking refuge in the United States.

(4) Mexico's population growth has slowed dramatically from 2 percent per year in 1990 (implying a population doubling every 35 years) to 1.3 percent in 2017 [30].

(5) In some places within the country, the impacts of climate change are apparent, and the prospects are for increasing impacts in the future. Hurricanes in the Caribbean and Pacific and droughts in Sonora and Sinaloa appear to be related to climate change.

(6) A new President, Lopez Obrador, brings in a new focus on eliminating corruption and recovering economic sovereignty. He faces, however, enormous social and political inertia from the corrupt regimes of the past, and the decline in oil output will continue to put stresses on the government, the people and the economy. 


\subsection{A Brief Biophysical and Economic History of Mexico}

The current economic situation in Mexico has its roots in the demise of the economic model known as "The Mexican Miracle". The Mexican Miracle, or The Economic Protectionist System, was modeled on and guided by the United Nations Economic Commission for Latin American and the Caribbean (ECLAC) after World War II, and based on the theories of Raúl Prebisch, which were precursors to what is known as "dependency theory". Prebisch's theory was stated in terms of neoclassical economics. He argued that poor (peripheral) countries, which specialized in primary (mostly agricultural) exports, possessed an elastic demand (due largely to the many substitutes for primary commodities). Developed nations of the Center (for example the United States) exported manufactured goods with a more inelastic demand. In this case, an expansion of trade would make revenues for the inelastic goods increase. Exporters of primary commodities would suffer from declining returns. In this case the terms of trade deteriorate and adversely affect peripheral nations (e.g., Mexico) in the case where the free play of market forces is unrestricted. This causes income to flow to the center and deepens the perpetuation of poverty. Prebisch advocated "Import Substitution Industrialization" whereby an increasing proportion of manufactured goods is supplied domestically rather than being imported [31]. Dependency theory had a great influence in Latin America in the years of the revolutionary movements from 1960 to 1980. Its roots are found in Marxist-Leninist imperialism theory. Marxist Latin American sociologists and economists such as Vania Bambirra and Theotonio dos Santos, along with European and African scholars such as Paul Baran, Andre Gunder Frank and Samir Amin, worked on the idea that the dominant international system was based on the exploitation of poor countries by industrialized nations with the participation of domestic elites. The economic surplus, a 20th century version of Marx's surplus value, was transferred to the developed countries in a process of unequal exchange. The lack of an economics surplus, which was the basis for investment and development, led to the perpetuation of poverty and the "development of underdevelopment" [32]. By the means of capital flows, the rich nations deformed underdeveloped countries' economic structures to serve the "Northern" nations that got access to natural resources. Dependency theory was interpreted by non-Marxist academics from ECLAC as a system of relations that could be reversed by import substitution strategies and aggressive industrial and agricultural protectionism.

The most important contribution to the discipline made by the ECLAC scientists was the Unequal Terms of Trade theory. With this approach, the Latin American economists explained the origins of the economic and geopolitical dependency of the region. The central idea of the permanent decrease in the exchange value of raw materials with respect to manufactured goods justified the industrialization strategy of the so-called "third world" countries [33].

This approach provided broad protection to state industries encouraged to produce for domestic consumption (import substitution), as well as collective subsistence farms called ejidos. It was the dominant and successful approach of the Mexican economy during the 1970s and until the economic crisis of 1978, when it seemed to have failed. However, the success of the protectionist model was not basically due to the consolidation of internal economic sectors, but due to the ability to extract oil reserves and the overexploitation of natural resources.

Despite the corruption related to the oil boom, the flow of economic resources created by it allowed the stability and the improvement of living standards of the Mexican population [34]. (This is an example of a biophysical analysis leading to a better understanding of political events).

The protectionist economic model found its limits at the end of the 70s due mainly to the loss of competitiveness of the national economy and the pressures of foreign capital to incorporate Mexico into the globalization process. 
The emergence of neoliberal ideology in the 1970s, with the neoclassical "Los Chicago Boys" intervention in the Chilean military coup, marked the end of the influence of the dependency theory in academic and governmental circles in Latin America. In Mexico, the De la Madrid administration implemented in 1982 a new economic model based on the dismantling of the protected economy and the welfare state and the establishment of a market-oriented economy. The consolidation of the new model took place through the implementation of the North American Free Trade Agreement in 1994. Under the new economic context, Mexico, the US and Canada reduced their trade and investment barriers and started an economic integration process.

The main macroeconomic results of the strategy of integration after 36 years are usually thought to be positive: domestic Gross Domestic Income (GDI) grew exponentially, 305\%, [35] and export grew $2,418 \%$ [36]. In the last 30 years, Mexico gave birth to a small group of a world-class financial elites, so that increasingly Mexicans were represented among the world's wealthiest people. However, behind these impressive quantitative results lies a more complex and contradictory reality: Mexico's economic, environmental and social challenges also grew exponentially. We will explore these challenges in greater depth in following sections. In 2019, Mexico's economy remains, by many accounts, fragile and even highly dysfunctional, and highly dependent on US trade and investment flows. Additionally, most regional ecosystems in Mexico are under great pressure, and $48.8 \%$ of the total population is officially living in poverty [37].

At the beginning of this economic integration transformation, the most important obstacle for the Mexican economy was its "lack of competitiveness". Given the existing structural asymmetries between, especially, the Mexican and US economies, the Mexican economy was in a vulnerable position. For example, in 1994 the Mexican share of the binational GDI was only 6.16\% [35]. The NAFTA negotiations led to the virtual assimilation of the Mexican economy into the US economy. The geopolitical consequences of the loss of Mexican sovereignty over its own economy have become more evident in the present stage of the binational relationship, with the recent pressures from the current US administration over the bilateral agenda (trade, migration or drug trafficking) increasing [38].

The overall result of the NAFTA economic integration process is the dependence of Mexico on foreign, mostly American, economic flows and the generation of a twofold economy in Mexico: a competitive sector, linked to US productive chains, capital and direction, with high participation in bilateral trade, and a low-income traditional sector with no access to foreign markets, capital or technology. Mexico, once a relatively equitable country, has become increasingly a country with a great divide between a small group of multimillionaires and millions of people living in conditions of poverty. The Gini coefficient (a measure of income inequity, whereby higher numbers indicate a greater degree of inequality) was 0.492 in 2014, placing Mexico as the 34 th most inequitable country among the OCDE members. By comparison, the most equalitarian country, Islandia, has a Gini coefficient of 0.246 [39].

\subsection{Labor Asymmetries}

While the current federal US minimum wage is $\$ 7.25$ per hour, in Mexico, workers get approximately $\$ 5.00$ per day. The wage gap between Mexico and the United States has had two main effects. On the one hand, the competitiveness of Mexican export companies increased. On the other hand, the low wages paid in Mexico caused the containment of wages in the United States (Figure 1). It is estimated that, as a result of the above, the participation of wages in the GNP of the United States decreased from $45.3 \%$ to $43 \%$ from 1994 to 2017 . This reduction reaches the sum of 443.2 billion dollars, almost the total sum of Mexican GDP. 


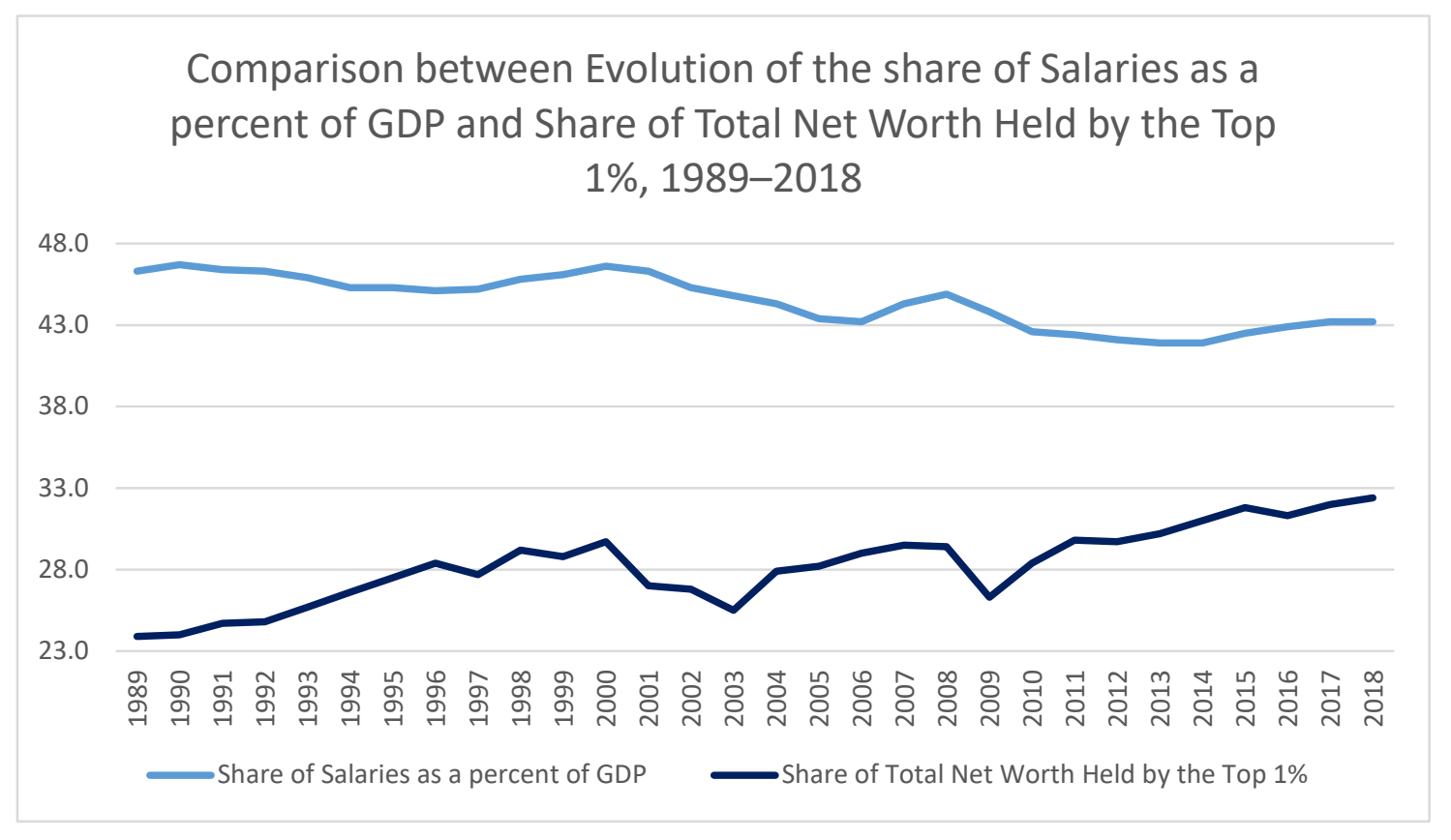

Figure 1. Comparison between evolution of the share of Salaries as a percent of GDP in the US (showing a general decline) and evolution of the share of Total Net Worth held by the top $1 \%$ (showing a general increase), 1989-2018. Own elaboration from [40,41].

The appropriation of Mexico's natural resources and their export to the United States was a second important consequence of NAFTA. The price differential in mineral inputs and water caused a drainage of Mexican resources to the US and the deterioration of many important ecosystems. The "flexible" (i.e., less restrictive) Mexican environmental laws act as an incentive for foreign direct investment. The situation is especially critical in the mining sector, where more than $13.5 \%$ of the national territory has been taken over by concessions belonging mainly to Canadian companies [42].

Until the decade of the 1980s, the Mexican foreign export sector was concentrated in crude oil exports (nearly $80 \%$ of total exports in 1982) (Figure 2) [43]. In those years, the Mexican state used the revenues generated in the international oil markets to achieve significant growth rates but also to create a corrupt class.

As a result of the integration process the structure of exports changed: oil-related exports decreased to $6.7 \%$ of the total exports in 2018. Despite the fact that crude oil exports diminished after 2006 due to the decline of the Cantarell complex reserves, the energy sector remained one of the decisive determinants of Mexican economic growth. Cheap and still relatively abundant oil reaffirmed its role as one of the pillars of the new economic model by subsidizing industrial and agricultural production. Nevertheless, even after 25 years of NAFTA, the Mexican economy did not reach the growth rates that characterized the former protectionist era. From 1935 to 1982, the Mexican economy grew 6.7\% per year, and from 1983 to 2002, the growth rate was only 2.2\% per year [44]. For 2019, estimated economic growth is less than $2 \%$ [45].

The integration process meant a total restructuring of the Mexican economy, the virtual disappearance of Mexican export capital (with the exception of a small group of industrial products such as cement and beer and agricultural commodities such as berries and avocados) and the concentration of external activity in a handful of US companies. 


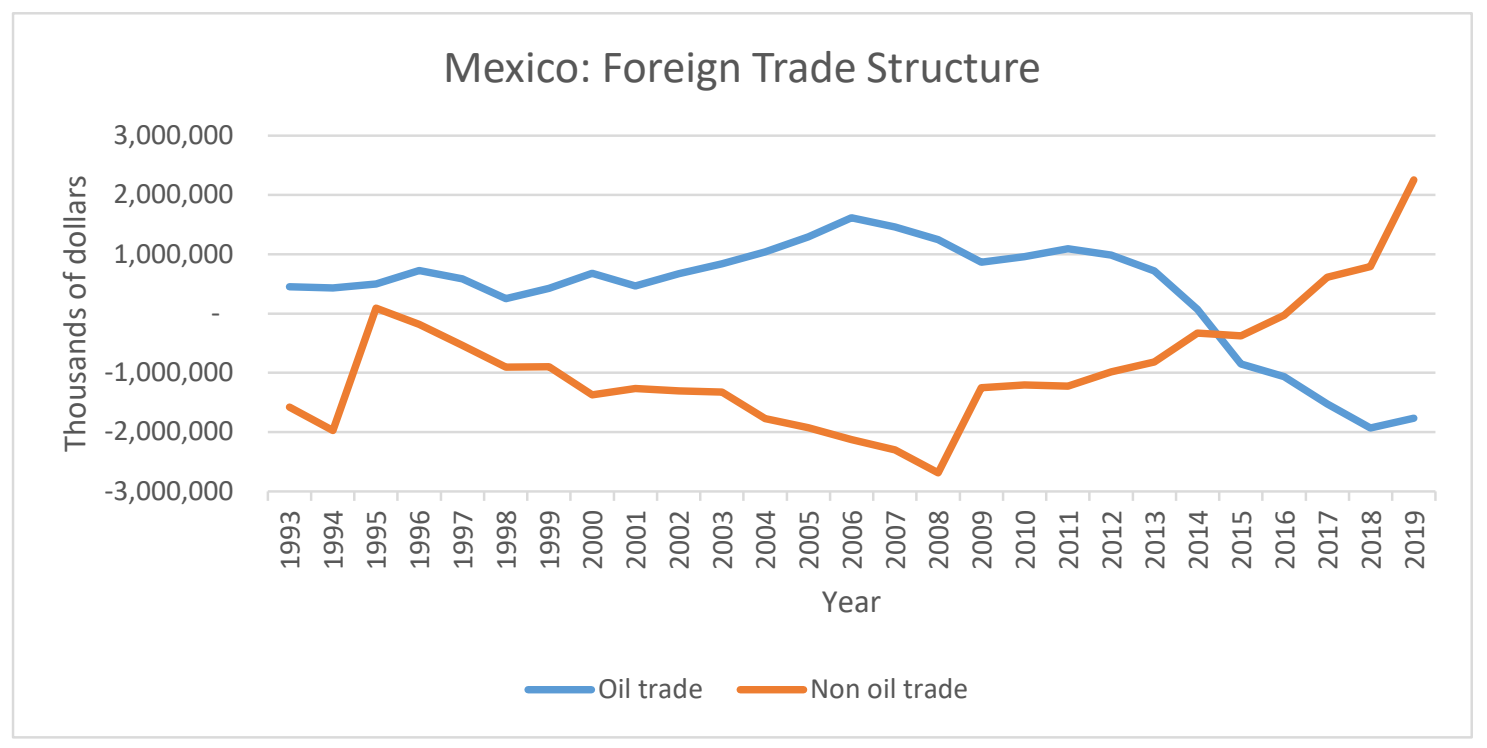

Figure 2. Mexican non-oil and oil trade balance 1993-2019. Own elaboration from [43].

The structure of the most important elements of Mexico's foreign trade illustrates the imbalances of the economy characterized by the predominance of American companies' participation in Mexico's "exports" (most of the exporting companies are American owned) [46]. According to the Secretary of Economy, 20 companies such as General Motors, Chrysler and Ford account for 32 percent of total exports [47].

We now turn to explore in more depth specific aspects of the Mexican economy that demonstrate the relevance of a biophysical approach to addressing the nation's economic challenges.

\subsection{The Mexican Agricultural Sector}

As a result of the implementation of the new economic model, agriculture was radically transformed. The new commercial opening strategy consisted in the promotion of "free competition" in the North American commercial zone. For this, the government deactivated the scheme of economic and institutional support for traditional Mexican farmers and led them to compete with the great agro-industrial capitals of Mexico and the US. The main outcome was the loss of the nation's food self-sufficiency. Traditional crops, such as maize and wheat, could not compete with cheap imported US grains from highly industrialized agriculture. Under the new conditions and with the existing overarching economic asymmetries, Mexican producers could not compete with American farmers. The US also has more favorable conditions for growing grains, and American grain producers receive massive government subsidies and use advanced technologies to enhance yields [48]. As a result, the agricultural focus of Mexico was reoriented toward high-value agricultural exports such as berries and avocados. The environmental impacts of this agricultural transformation include the deterioration of water quality and the exhaustion of Mexican water reserves in regions where exporting agribusiness are located [48]. The disruption of nitrogen and phosphorus cycles is also an important environmental emergency in Mexican rural areas. Cheap oil and federal subsidies contribute to the overuse of fertilizers by peasants and agribusiness entities. As a result, most important lakes and reservoirs in harvesting areas suffer from permanent or seasonal eutrophication and, as rivers reach the oceans, eutrophying nutrients affect mangroves and coral populations [49]. 
The exhaustion of natural resources and the critical economic situation in rural communities is at the root of the migration crisis to the US, which was especially acute in the 1990s after the passage of NAFTA. The adverse situation that faced the Mexican peasantry, most of whom cannot compete economically with cheap US grains or switch to high value specialized crops, forced millions of Mexican campesinos to migrate to Mexican cities, border area maquiladoras, or in the past to the US to earn money to support their families. Historically, the funds sent by Mexican emigrant workers to their families were the most important source of international revenues. In 2018, such revenues were the largest source of foreign currency for the nation ( $\$ 28$ billion), followed by the sales of oil products ( $\$ 26$ billion) and tourism ( $\$ 16$ billion) [50].

The situation facing the peasantry was made clear to the second author when he visited Yucatan in 2010. New "investment" of, apparently, United States Aid dollars in the form of an $8 \mathrm{~km}$-long dock built out into the Gulf of Mexico was clear, turning Yucatan into a deep-water port (Puerto de Progreso) to enhance, along with NAFTA, foreign trade. One main effect of the project appeared to be to undermine the local peasantry, for the locally grown maize (corn), the staple (as tortillas) of the Mexican peasant diet, was essentially eliminated because US maize from the Midwest was cheaper in local markets (although this price structure worked to benefit local large-scale livestock growers).

The first biophysical advantage that the US has is that it is located at temperate latitudes. This is critical for maize (corn) production because in Iowa in the growing season the day/night relation is 16 hours' daylight to 8 hours of night. At night maize (or any plant) requires energy for its own respiration, and this is enhanced when nights are warm [51]. Thus, if one plots maize yield vs. pole-to-pole latitude for agricultural experimental stations (with presumably all good management practices for their locality) from all over the world one gets a U-shaped curve. The lowest yield (about 1-2 tons/hectare) is in the tropics, and then yield increases through the subtropics and up to about 50 degrees' latitude North and South. Thus, there is a severe biophysical constraint on the production of maize (and maybe other crops) for Mexico, no matter the management or inputs [51].

\subsection{Mexican Manufacture}

With the new economic integration model initiated under NAFTA, with few exceptions, the Mexican industrial sector became an input supplier of the American economy. In most recent decades, most Mexican important manufacturing companies either disappeared or were assimilated by American firms. Only a handful of Mexican-owned companies still compete in the US market [52,53].

Maquiladoras, factories along the US border generating goods for US consumption, became the most important "industrial" activity in Mexico. Their share of industrial exports reached 70\%, and they generate more than one billion dollars per year in the national balance of payments [54]. By definition, these sweat shops provide only cheap labor: all other productive factors (technology, inputs and capital) are brought from abroad. These companies, the prototype of the economic integration model, are not integrated within the Mexican productive chain. Still, they usually receive preferential fiscal treatment (i.e., receiving tax benefits while still requiring tax-supported services) and, in most cases, cause important environmental damage. Frequently, maquiladoras use hazardous materials, and, by contract, foreign contractors leave these materials on the Mexican side of the border. This practice has become an environmental emergency in maquiladora zones such as Guadalajara's Santiago River. As a result, the most important river in the Mexican West is considered an environmental catastrophe [55].

The restructuring of the industrial sector caused by the external development model has led to the disappearance or assimilation of most Mexican companies by US capital. It follows that the study of the socio-environmental risks of integration is a pending subject in the university curriculum. 


\subsection{The Mexican Service Sector (Tourism)}

Under the NAFTA-based integration model, and the price differential for labor and services between Mexico and the rest of the world, foreign tourism became one of the most important Mexican economic activities. The local tourist sector has been neglected by official policy [56,57].

The main offer in the foreign tourism market is Mexico's "five star" beach locations. Mainstream beach tourism has had important environmental consequences in places such as the Yucatan peninsula and the Jalisco coast. Reports indicate that both mangrove reserves and coral populations suffer a process of permanent deterioration as a consequence of the rapid growth of upscale tourism [58].

Given the economic importance of the environmental services provided by tourist areas, the absence of the biophysical perspective in the conception and implementation of tourism projects is inexplicable.

\subsection{Regional Development}

The economic model chosen by Mexican decision makers to guide foreign economic investment or development flows had a strong impact on regional development or lack thereof. In Mexico, international capital and trade flows have been concentrated in relatively few zones located near urban nodes like Mexico City in the center of the country, the western region (Guadalajara) and the northeast (Monterrey). The rest of the country does not participate in the development process, nor are their economies integrated with regions that receive investment funds. Hence, they tend also to be left out of the development programs of the Federal government. Internal migration trends show the movement of people from the South and other neglected areas to the main urban centers, often causing problems at both ends of the migration [59].

Accelerated demographic concentration in main cities provokes important social and environmental bottlenecks that cause local governments chronic financial deficits and push them to the verge of governance crisis. From the environmental side of the crisis, modern cities have serious challenges related to waste management, air pollution, urban deforestation and water shortages. They may or may not be more energy-intensive per capita than other regions. The social impacts of uncontrolled urban concentration and the lack of job opportunities for the population in new megacities generate increases in crime and the proliferation of informal and illegal activities. In some cases, these activities, such as gasoline trafficking, are the main modus operandi of new towns [60]. This new situation has transformed the social structure of the international migration process, adding to the traditional campesino flows out of rural areas and creating new urban middle-class immigrants [50].

Finally, it should be considered that the most important economic activity in national development is the energy sector. Both for its specific weight in the economic structure and for its socio-environmental implications, energy generation and trade constitute the cornerstone of the current development model. This has been established by the new government with its energy transition project.

\subsection{The Energy Transition}

Mexico used to be a major oil exporting country. Since its nationalization in 1938, the oil sector became the main engine of national development.

Current official information states that oil reserves total 25,000 million barrels-these would last only 30 years at the current rate of extraction [61] (Figures 3 and 4). 


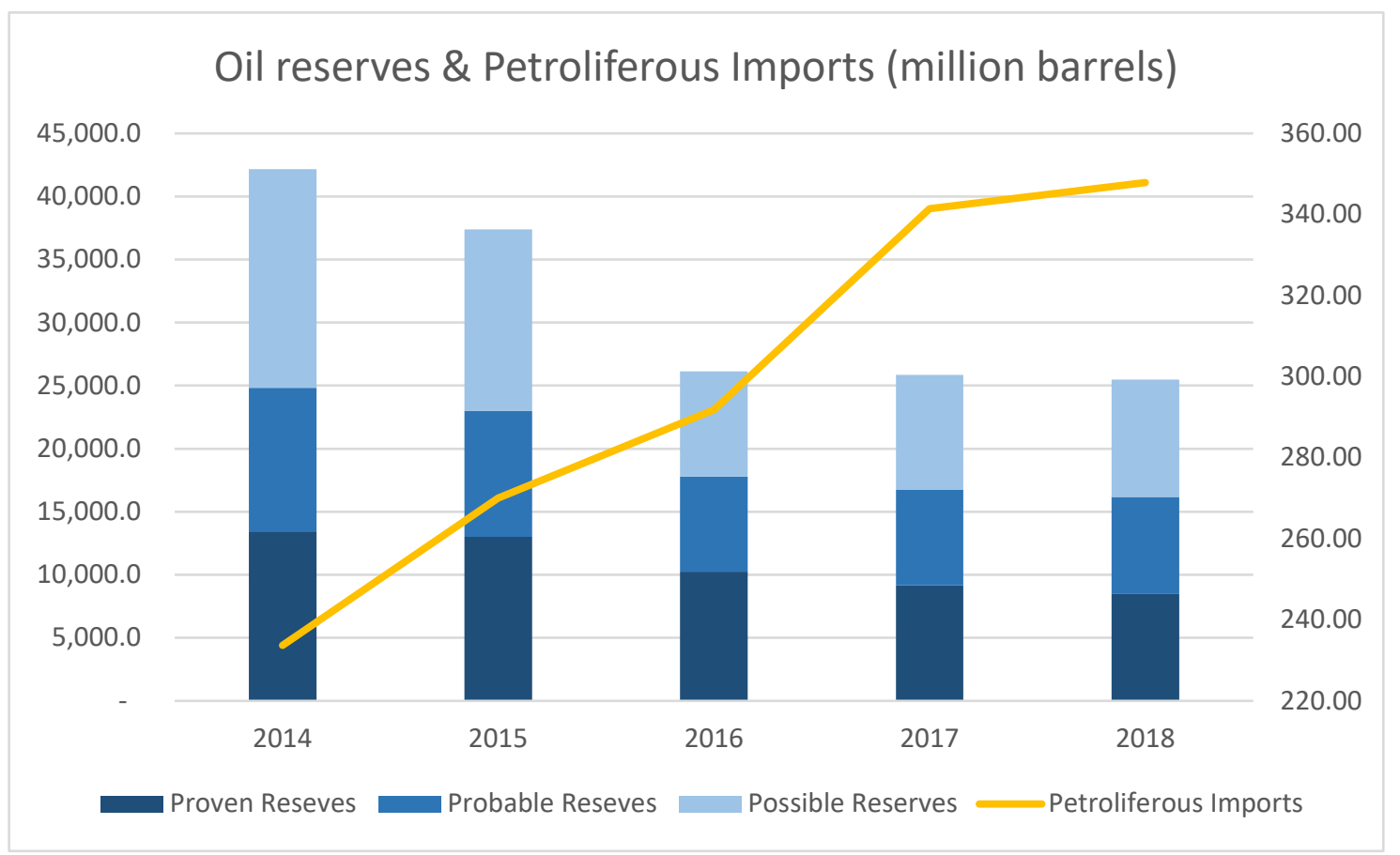

Figure 3. Mexico's official estimates of oil reserves (million barrels), which have been enormously affected by continued depletion as production has declined more rapidly than use. Own elaboration from $[61,62]$.

The decrease of the revenues obtained from Mexican oil sales created a deficit in the federal budget. To resolve the problem, governmental revenues have been replenished by increases in energy consumption taxes. With the new situation the price of gasoline increased by $83.04 \%$ from 2012 to 2018 [63]. On the one hand, the government applied an extra consumption tax and on the other, it liberalized its prices in accordance with international markets. This of course led to social disruption as outlined above and by Ahmed [13].

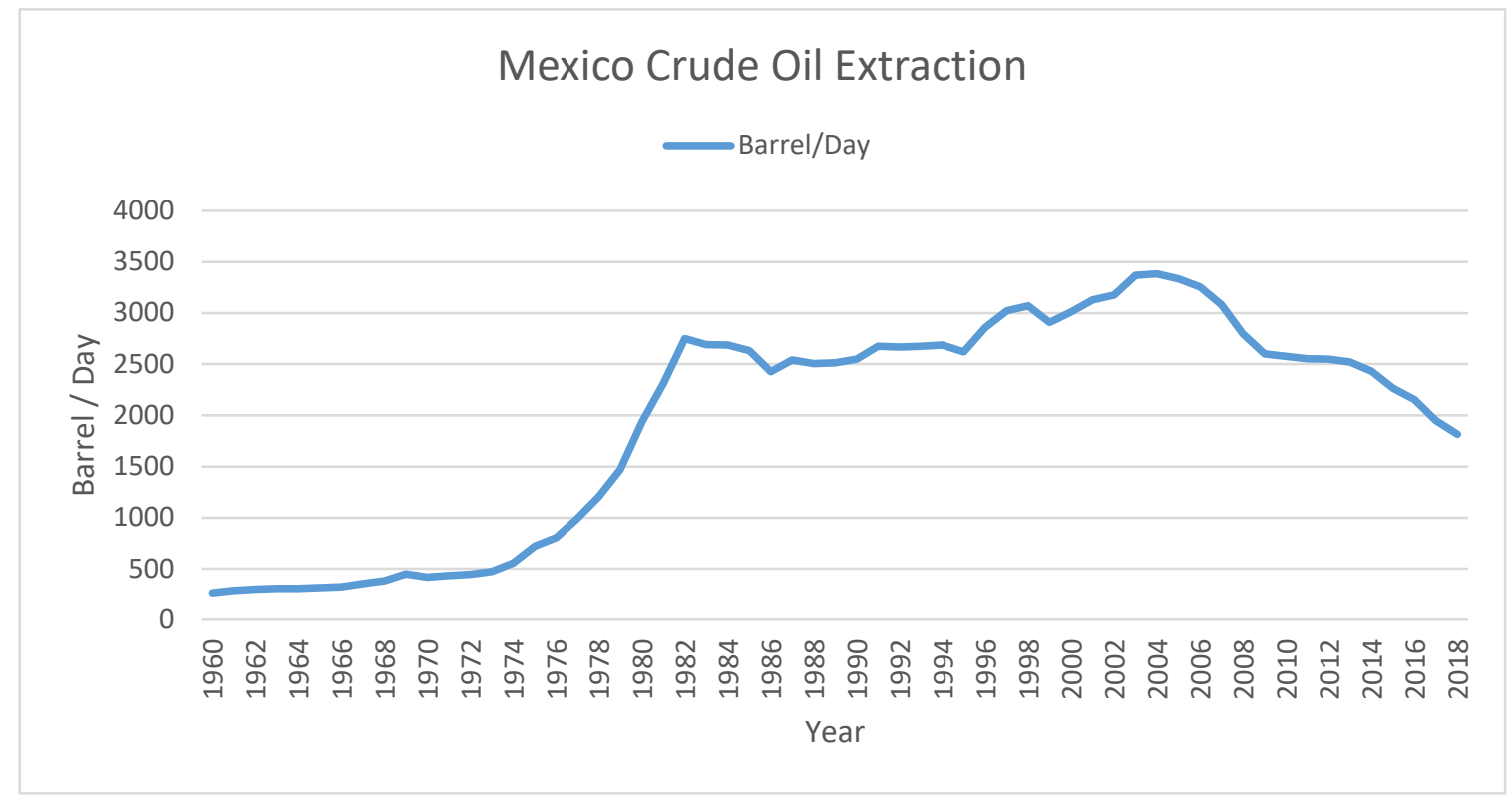

Figure 4. Dynamics of Mexico's oil extraction ("Peak oil" 1960-2018). Own elaboration from [64]. 
Accordingly, the former Peña administration implemented a new energy strategy. For the first time in Mexican history, the new plan allowed the participation of foreign investment in the exploration and extraction of new sources of oil.

The new government of President López has proposed a fundamental change in the energy strategy. The new policy does not cancel the contracts agreed upon during the previous government. However, it emphasizes the administrative and productive recovery of the national oil company, PEMEX. The importance of national ownership of natural resources, including oil reserves, derives from the nationalist tradition of the Mexican state and the negative effects caused by energy dependence on foreign sources to a poor and vulnerable country like Mexico.

This policy focuses on intensified field exploration and the acceleration of oil and gas extraction, although it is not clear whether this energy-intensive activity can reverse the downward trend of production. Thus, because the "easy" oil has been used up, the production of oil now (especially off shore) is faced with increasing energy cost, and hence lower EROI (Energy Return On Investment). It should also be pointed out that "pushing" the Cantarell field, once the world's second largest, with nitrogen injection appeared to precipitate its collapse. These factors, along with lower oil production, will cause significant strains on a Mexican economy that has become used to cheap and abundant petroleum.

Nevertheless, the official position is that, with the construction of new oil refineries, PEMEX will recover its strategic position for the development of the country. The official prediction is that GDI will increase by $4 \%$ during the next six years based on the expectation of increased oil production $[65,66]$.

The new elected government of President López has initiated a transformation of the economic model that led Mexico to the current situation. With regard to economic policy, the authorities have reconsidered the role of the state, making it an instrument to redistribute income through aggressive income support policies for the most vulnerable groups in society [66]. The model, inspired by the Keynesian theory of the promotion of domestic demand, aims to reverse the concentration of wealth through mechanisms such as progressive tax collection, savings in public spending and the fight against corruption. However, in environmental matters, the new government has prioritized investment in megaprojects for development that, despite being under intense international and citizen scrutiny, are promulgating the integration model of the last century with the result of its reproduction, along with its consequences for nature and culture. In addition, these megaprojects demand a large amount of energy from an extractive system that is experiencing a decline.

However, what can a petroleum-dependent economy do when, as seems inevitable, petroleum production has decreased nearly by half and is likely to continue to decrease for the foreseeable future? It would seem that Mexico is a perfect candidate for the political unrest and increasing social stress laid out by Nafeez Ahmed in his book Failing States, Collapsing Systems: Biophysical Triggers of Political Violence [13], especially if citizens do not understand that, besides the political crisis, the problems are of biophysical origin.

It is clear that the economic integration model pulls resources from Mexico, causes damage to lands and coastal areas and leaves the nation more vulnerable in terms of resources.

Thus, it is critically important for young Mexicans to understand Biophysical Economics. Still, these issues barely get attention in governmental circles and the press. Perhaps the reason is that they are not a focus for conventional economists, and this is in large part due to a lack of appropriately trained economists. We turn next to the issue of training Mexican economists appropriately so that they might address the biophysical underpinnings of the multifaceted economic challenges of the nation.

\section{Teaching Economics in Mexico}

It is clear that Mexico is faced with a set of changes that are basically biophysical in nature. Yet the approaches offered by the government and by academia to deal with these issues tend to be based on conventional economics, with little mention of the biophysical roots of the underlying issues. The challenges that the Mexican society faces in the near future are difficult, multiple and 
interrelated. The main requirement for social and economic health is to obtain sufficient energy and natural resources to meet the needs of a still growing and largely poor population (148 million people in poverty in 2015) [50]. These goals must be achieved in the context of an asymmetric and sometimes hostile relationship with Mexico's neighbor and main business partner: The United States. Of greater concern, students at most Mexican universities continue to be trained in conventional economics, mostly mainstream economics, based on markets and consumer preferences and increasingly influenced by political neo-conservatism. Furthermore, the development strategies of the new government, usually generated by neoclassical economists, are not based on objective evaluations of the resources with which Mexico can confront the future.

Of particular concern are the ingrained perspectives in Mexico, and indeed nearly all Western and other societies: that economic growth is the single solution to all problems of poverty and is, therefore, to be desired above essentially all other social goals; that children should have a higher material standard of living than their parents; that it is socially responsible for media to be saturated with advertisements for "more", often far more than is required for health or satisfaction; that a good politician is one who will bring more jobs and higher wages indefinitely; and other related notions. While it is difficult to conceive of society breaking from these traditions, it is equally impossible to conceive of a society based largely on oil revenues and oil consumption achieving these goals while oil production and EROI decline. Certainly, using a biophysical approach to economics, Mexican students, economists and policy makers can begin the process of questioning all of these concepts. Whatever path is chosen, the recent decline in Mexican birth rates will greatly facilitate the transition to the future.

It that Mexico needs, and will increasingly need, economists and other managers of the economy that are trained to understand the biophysical bases for economic activities and to translate this understanding into policy. At a minimum, much more natural science, including environmental science, needs to become a foundation for a degree in economics. The need for such training can be seen already in the job opportunities available in Mexico in the new technology industries, the green economy and the public sector. In general, the necessary training does not seem to be taking place, and in fact education in Mexico and elsewhere is increasingly focused into intense training in sub disciplines.

Fortunately, within Mexican higher education institutions, the rejection of neoclassical economics is growing. Students and their professors have started to wake up to the reality of the actual situation of the Mexican economy and have started thinking of options, visions and ideas that can help them understand the complex relationships among economy, ecology and society. A new type of human ecology is desired, but neither students nor faculty know exactly where to turn for an integrated and deeply contextualized approach to economics, let alone how to apply it. In China the problem with neoclassical economics is understood by political leaders, and there seems to be strong impetus to use Ecological Economics or perhaps Biophysical Economics as a new base for their economics teaching. This may be especially important if and as new viruses (a biophysical agent not considered within conventional economics) become more prevalent.

The idea of limits to traditional growth-oriented economics, of course, brings up the question-are we arguing for keeping the poor in continual poverty? Of course not: we wish the poor to have a decent material life and argue that, contrary to what policy makers do now, a political emphasis on decreasing the population and on a much greater sharing of whatever wealth is produced would generate much better conditions for the poor than what they experience now or are likely to obtain from the aggregate growth of the economy alone. Indeed, although growth is the only tool for economic wellbeing currently promoted in most countries, it may no longer be possible in Mexico and in a growing number of countries. Even many "sustainable" economic programs argue for "sustainable growth" or, basically, maintaining present conditions. Likewise, attempting to pour neoclassical dogma into a nation with leveling or declining oil production can also cause much unnecessary social and environmental harm [13].

At the present time, with the arrival of the new Federal administration in Mexico, there has been greater support, in universities and research centers, for the study of heterodox economic theories. 
This new interest in diverse economic ideas has resulted in a greater discussion about the scientific foundations of mainstream economic science and the opening to new economic paradigms. These shifts encounter great opposition in consolidated academic circles that have imposed their vision of the economy and society for the past 50 years.

\section{Discusion: University of Guadalajara, an Opportunity for Change in Economics Education}

We think that Biophysical Economics offers an approach to deal with the problems of Mexico as they are, with integration of both biophysical and social perspectives. Toward that end, we offer as an example a program that we are developing at the University of Guadalajara.

At the University of Guadalajara, with the support of the academic authorities such as Maestro Ricardo Villanueva Lomelí, the President of the University, Maestro L. Gustavo Padilla Montes, the Director of the University Center of Economic Sciences, and Doctor Martín G. Romero Morett, the Dean of the Economics Department, the faculty has started to develop a new academic approach along with new programs in economic sciences that can transform the way faculty and students think about society and the approaches they consider in the classrooms. In the process, the University of Guadalajara received the assistance of international experts, including doctors Charles Hall, Robert Costanza, Joan Martinez, Aleida Azamar, Sabine O’Hara and Kristin Vala, who collectively gave a mostly consistent view as to what the University needed to do: stop using conventional economics as a basis for the curriculum, and focus instead on ecological economics and especially biophysical economics. The goal of implementing these changes is to create an ecological literacy educational system, as Capra [67] would say, among the students of the University of Guadalajara.

It is clear that the University Center for Economics and Management Sciences (CUCEA) at the University of Guadalajara is very well equipped to step into the economics lacunae discussed in this article. They have popular, well-financed programs that attract many top students and that have an excellent national reputation. Given that the entire University is large and diverse, the basic resources are in place to undertake a transition from strictly conventional economics to a broader, systems-based program in Biophysical Economics. A critical issue for such a program to address is what kind of economic growth is possible/desirable with the decreasing biophysical resource base in Mexico.

Our program would emphasize the teaching of how to quantify the energy and other resources used both by existing and by alternative economic activities as a basis for making policy decisions that support social, economic and environmental health while recognizing natural limits, including whether the resources are available to undertake whatever plans are put forth. It is our opinion that many existing "sustainable" or "green" programs are not that at all, but rather look or sound green without having had their real footprint (including the energy costs) analyzed or quantified.

The authors of this paper have worked together to try to bring a project in Biophysical Economics into existence at the University of Guadalajara and more generally in Mexico. Charles Hall visited the University in March of 2017 and was extremely impressed with the potential for developing a more comprehensive approach to economics. Most important for this purpose were the openness and understanding of the Department Chair Martin Romero and Professor Salvador Peniche, with whom he had been interacting over several previous years. The visitors also met with other very interesting people in different disciplines as well as economics and visited the limnology field station at Ajijic. All economists were well aware of the general criticisms of economics such as those of Piketty [20] and Krugman [25], and many were sympathetic that a new approach was badly needed, although exactly what was not yet clear. Other distinguished economists who are quite critical of conventional economics, including Joan Martinez-Alier, Paul Sutton, Mario Perez, and Aleida Azamar have also presented at the Department and have been well received.

Hall presented in a series of lectures based on the outline of a "biophysical" approach to economics that he had been developing over many decades as professor at Cornell University and the State University of New York. The essence is presented in [26] and in great detail in $[21,27,28]$. There has not been a student among the hundreds that have taken the Biophysical Economics course that to 
his knowledge has rejected the approach, and most were extremely enthusiastic, mostly because, in contrast to conventional economics, it was consistent with what they were learning in other courses in the science-based institutions where he taught. The concept of Biophysical Economics and broad training in natural sciences for economists has gained wide international interest among economists, scientists, investors and others especially in Europe and China. There has been an official endorsement by the Chinese government for making the concept of Ecological Economics (including Biophysical Economics) the official basis for teaching economics in China. While this concept has hardly penetrated the ranks of conventional economists, it is clear that the time is ripe for broadening the base of economics in Mexico especially, and elsewhere. We find this very exciting.

Hall and Klitgaard have developed over the years a series of courses and books that could form the basis for new programs in Biophysical Economics. All of them were developed from a systems vs. a disciplinary perspective. They are outlined in Table 1. Most important is to start at the freshman level with an interdisciplinary approach. Hall taught such a course to freshmen, called "The Global Environment and the Evolution of Human Culture", for nearly 20 years. That course includes some basic Earth properties (including the interactions with the sun that generate global weather patterns), the ways that these weather patterns generate regional climates (e.g., why is much of Northern Mexico dry and southern Mexico wet) and these in turn ecosystem types (deserts vs. tropical rain forests), then a section introducing Darwinism and how that operates generally and then with humans, then a review of human cultural evolution starting with hunter-gatherers, then the evolution of agriculture, and then the evolution of industrial society. All of this is done focusing on the energetics of each process, so that by the time the class reaches modern industrial society it is perfectly logical to consider it from an energy perspective. Economics is viewed as the process by which humans exploit nature, using increasing amounts of energy, to generate goods and services that are then distributed in markets or by other means. In each step of the human economic development the total energy used per person and the EROI is considered, showing how our modern society is ever more energy intensive.

Table 1. Possible template for a program in the Department of Energy, Economics and Environment.

\begin{tabular}{|c|c|c|}
\hline Year & Core Courses (All Must Take) & Additional Requirements (Flexible) \\
\hline Freshman & $\begin{array}{l}\text { The global environment and the } \\
\text { evolution of human society; } \\
\text { Principles of micro and } \\
\text { macro economics }\end{array}$ & $\begin{array}{c}2 \text { (or more) semesters of science; } \\
\text { Physics, Chemistry and/or Geology; } \\
\text { Quantitative thinking; } \\
\text { Logic and History of Scientific Methods }\end{array}$ \\
\hline Sophomore & $\begin{array}{l}\text { Business and social ethics; } \\
\text { Dependency and development } \\
\text { political economy }\end{array}$ & $\begin{array}{c}\text { Ecology; } \\
\text { Calculus (3 semesters?); } \\
\text { Theories of Political Economy; } \\
\text { Ecological Economics. }\end{array}$ \\
\hline Junior & $\begin{array}{l}\text { Biophysical economics; } \\
\text { Mexican ideals and institutions; } \\
\text { History of economic thought }\end{array}$ & $\begin{array}{c}\text { Start Concentration; } \\
\text { Energy }\end{array}$ \\
\hline Senior & Sustainability & $\begin{array}{c}\text { Urban Ecology; } \\
\text { Systems Ecology (perhaps); } \\
\text { Senior Project }\end{array}$ \\
\hline
\end{tabular}

Note: Charles Hall has experience, syllabi, recorded lectures and textbooks for most of these courses. Kent Klitgaard has also taught all of the economics courses on this list, and can provide syllabi and exams as well.

Subsequent courses that we propose all students take include some basic sciences, the usual math and statistics, and most importantly, Biophysical Economics. Then students will take tracks depending on their interests, but all will converge for courses on ethics, climate and the economy and the future energy possibilities for Mexico. We include one idea for a set of courses in Table 1 , but the actual implementation would depend very much on the personnel, resources and specifics of the particular application. 
There are a number of ongoing international institutions and activities that would assist in this process and help gain ideas, opportunities and colleagues from around the world. The International Society for Biophysical Economics is an active group with approximately annual meetings and a membership of several hundred economists, scientists, financial and business-people and others. This Special Issue of the journal Sustainability on "Advances and Innovations in Sustainability Education: Higher Education as an Avenue for Social Change" edited by our colleague Dr. Tina Evans, should bring attention, critiques and assistance to this particular program.

The "systems" training that was once vibrant in North America has largely disappeared with the retirement and sometimes death of its leaders including Kenneth Boulding, Jay Forrester, Donella and Dennis Meadows, Buzz Holling, Bernie Patten, Howard Odum, Hermann Daly and Bolivar Echeverría. While some of their students, such as ourselves, are still active, there are relatively few "grandchildren" to take on the mantle, and little university support. Perhaps the University of Guadalajara and its leaders could take on this mantle?

\section{Conclusions}

The incorporation of the ecological perspective in the university curriculum at the University Center of Economic-Administrative Sciences of the University of Guadalajara occurs in the context of the environmental transition of the country and the region, derived from the perspectives of economic and demographic growth of the next years. Given the perspectives of the national regeneration process of the new government, the need to understand economic phenomena from a biophysical perspective will become a priority.

Biophysical economics allows for effective accounting of natural reserves, energy and entropy processes that allows governments to maintain cycle stability and economic growth within the limits of resilience.

The situation in Mexico, after decades of neoliberal economic policies of North American economic integration and liberalization of government regulations on the environment, becomes more complex in the sense of the overlapping of phenomena that are part of the network of consequences of the various Governmental and citizen socio-economic intervention spaces. The current political, economic and social situation allows us to hope for the possibility of implementing an effective and real exercise in modifying the economic training system in the state universities.

Author Contributions: Conceptualization, C.A.S.H., S.P.C. and K.K.; methodology, C.A.S.H. and K.K.; validation, S.P.C., C.A.S.H. and K.K.; formal analysis, C.A.S.H.; investigation, S.P.C., C.A.S.H. and K.K.; data curation, S.P.C.; writing-original draft preparation, S.P.C., C.A.S.H. and K.K; writing-review and editing, S.P.C.; supervision, S.P.C.; All authors have read and agreed to the published version of the manuscript.

Funding: This research received no external funding.

Conflicts of Interest: The authors declare no conflict of interest.

\section{References}

1. Altamirano, T. Refugiados Ambientales: Cambio Climático y Migración Forzada, 1st ed.; Fondo Editorial de la Pontificia Universidad Católica del Perú: Lima, Perú, 2014.

2. Novillo, N. Cambio climático y conflictos socioambientales en ciudades intermedias de América Latina y el Caribe. Let. Verdes Rev. Latinoam. Estud. Socioambientales 2018, 24, 124-142. [CrossRef]

3. Oswald, Ú.; Serrano, S. Riesgos Socioambientales, Paz y Seguridad en América Latina, 1st ed.; Universidad Autónoma de México, Centro Regional de Investigaciones Multidisciplinarias: Cuernavaca, Mexico, 2018.

4. Silva, T.; Carvalho, J.; Vieira, U. Geografía física, riesgos socioambientales y cambio climático. Rev. Geogr. Am. Central 2011, 2, 1-13.

5. Toscana, A.; Hernández, P. Gestión de riesgos y desastres socioambientales: El caso de la mina Buenavista del cobre de Cananea. Investig. Geogr. 2017, 93, 1-14. 
6. Dale, S.; Fattouh, B. Peak Oil Demand and Long-Run Oil Prices. Available online: https://www.bp.com/content/dam/bp/business-sites/en/global/corporate/pdfs/energy-economics/bppeak-oil-demand-and-long-run-oil-prices.pdf (accessed on 25 February 2020).

7. Bertoni, R. Energía y Desarrollo: La Restricción Energética en Uruguay Como Problema (1882-2000), 1st ed.; Ediciones Universitarias: Montevideo, Uruguay, 2011.

8. CLACSO: Protestas y Repression en Haití. Available online: https://www.clacso.org/comunicado-ante-lasituacion-de-haiti/ (accessed on 25 February 2020).

9. El Heraldo: Bloquean Por Más de Dos de Dos Horas vía Barranquilla-Santa Marta Por Falta de Energía. Available online: https://www.elheraldo.co/magdalena/bloquean-por-mas-de-dos-horas-barranquilla-santamarta-por-falta-de-energia-641917 (accessed on 25 February 2020).

10. Linkohr, R. La política energética latinoamericana: Entre el Estado y el mercado. Nueva Soc. 2006, 204, 90-103.

11. Hallock, J.; Wu, W.; Hall, C.; Jefferson, M. Forecasting the limits to the availability and diversity of global conventional oil supply: Validation. Energy 2014, 64, 130-153. [CrossRef]

12. Mushalik, M. Uncertainties Following the Abqaiq Attack Have Shrunk the World's Safe Oil Reserves by Around Half. Available online: http://crudeoilpeak.info/uncertainties-following-the-abqaiq-attack-haveshrunk-the-worlds-safe-oil-reserves-by-around-half-part-1 (accessed on 25 February 2020).

13. Ahmed, N. Failing States, Collapsing Systems: Biophysical Triggers of Political Violence, 1st ed.; Springer Nature: New York, NY, USA, 2017.

14. Abernethy, V. Optimism and Overpopulation. Atl. Mon. 2018, 274, 84-91.

15. Kenneth, J. A History of Economics: The Past as the Present; Penguin Books: London, UK, 1987.

16. Maynard, J. The General Theory of Employment, Interest, and Money; Palgrave Macmillan: London, UK, 1936.

17. Samuelson, P.A. Economía, 18th ed.; McGraw-Hill: New York, NY, USA, 2013.

18. Polanyi, K. The Great Transformation: The Political and Economic Origins of Our Time; Beacon Press: Boston, MA, USA, 2001.

19. Hall, C.A.; Cleveland, C.J.; Kaufmann, R. Energy and Resource Quality: The Ecology of the Economic Process; Wiley Interscience: Hoboken, NJ, USA, 1986; Volume 577.

20. Piketty, T. Capital in the Twenty-First Century; Harvard University Press: Cambridge, MA, USA, 2014; Volume 696.

21. Hall, C.A.; Klitgaard, K. Energy and the Wealth of Nations: An Introduction to Biophysical Economics, 2nd ed.; Springer: New York, NY, USA, 2018.

22. Martínez, A.J.; Roca, J.J. Economía Ecológica y Política Ambiental, 2nd ed.; Fondo de Cultura Económica: Ciudad de México, México, 2013.

23. Pengue, W. Fundamentos de la Economía Ecológica; Kaicron: Mendoza, Argentina, 2009.

24. Latouche, S. L'invention de l'économie; Albin Michel: Paris, France, 2005.

25. Krugman, P. How Did Economists Get It So Wrong? Available online: https://www.nytimes.com/2009/09/06/ magazine/06Economic-t.html (accessed on 25 February 2020).

26. Hall, C.; Lindenberger, D.; Kümmel, R.; Kroeger, T.; Eichhorn., W. The Need to Reintegrate the Natural Sciences with Economics. BioScience 2001, 51, 663-673. [CrossRef]

27. Hall, C.; Klitgaard, K. The Need for, and the Growing Importance of, Biophysical Economics. Curr. Anal. Econ. Financ. 2019, 1, 75-87.

28. Melgar, M.R.; Hall, C.A. Why Ecological Economics Needs to Return to its Roots: The biophysical foundation of socio-economic systems. Ecol. Econ. 2020, 169, 106567. [CrossRef]

29. Hall, C.A.; Matossian, P.D.; Ghersa, C.; Calvo, J.; Olmeda., C. Is the Argentine National Economy Being Destroyed by the Department of Economics of the University of Chicago? Available online: https://www.academia.edu/28209082/Is_the_Argentine_National_Economy_being_destroyed_by_ the_Department_of_Economics_of_the_University_of_Chicago (accessed on 25 February 2020).

30. Public Data: Tasa de Crecimiento Demográfico. Available online: https://www.google. com.mx/publicdata/explore?ds=d5bncppjof8f9_\&met_y=sp_pop_grow\&idim=country:MEX:USA: BRA\&hl=es\&dl=es\#!ctype $=1 \&$ strail=false\&bcs=d\&nselm=h\&met_y=sp_pop_grow\&scale_y=lin\&ind_ $\mathrm{y}=$ false\&rdim=region\&idim=country:MEX:USA:BRA\&ifdim=region\&tstart=-314388000000\&tend= 1484460000000\&hl=es\&dl=es\&ind=false (accessed on 25 February 2020).

31. Prebisch, R. Commercial Policy in the Less-Developed Countries. Am. Econ. Rev. 1959, 49, 251-273. 
32. Barone, C. Marxist Theories of Imperialism; M.E. Sharpe Inc.: Armonk, NY, USA, 1985.

33. Maizels, A.; Palaskas, T.B.; Crowe, T. The Prebisch-Singer Hypothesis Revisited. In Development Economics and Policy; Sapsford, D., Chen, J., Eds.; Palgrave Macmillan: London, UK, 1998.

34. Ramírez, P.C.; Hall, C.A. The relation of oil to the Mexican economy: Past, present and future. In Ecological Dimensions for Sustainable Socio Economic Development; Reyes, E., Day, J.W., Dávalos, S.R., Eds.; WIT Press: Southampton, UK, 2013; Volume 636.

35. GNI, Atlas Method (Current US\$)—Mexico United States. Available online: https://data.worldbank.org/ indicator/NY.GNP.ATLS.CD? end=2018\&locations=MX-US\&name_desc=false\&start=1962\&view=chart (accessed on 25 February 2020).

36. Exports: Value Goods for Mexico. Available online: https://fred.stlouisfed.org/series/XTEXVA01MXM667S (accessed on 25 February 2020).

37. CONEVAL: Medición de la pobreza en México. Available online: https://www.coneval.org.mx/Medicion/ Paginas/PobrezaInicio (accessed on 25 February 2020).

38. Chabat, J. La política exterior de México en la era Trump. Méx. Cuenca Pac. 2017, 6, 9-12. [CrossRef]

39. Evolución de la desigualdad: CEPAL, OCDE, Banco Mundial. Available online: https://www. coneval.org.mx/SalaPrensa/Documents/Informacion-debate/GINI-Comparativo-internacional.pdf (accessed on 25 February 2020).

40. Shares of Gross Domestic Income. Available online: https://fred.stlouisfed.org/series/W270RE1A156NBEA (accessed on 25 February 2020).

41. Share of Total Net Worth Held by the Top 1\%. Available online: https://fred.stlouisfed.org/series/ WFRBST01134 (accessed on 25 February 2020).

42. Azamar, A.A. Minería en América Latina y México: Problemas y Consecuencias, 1st ed.; Universidad Autónoma Metropolitana: Ciudad de México, México, 2018.

43. Sistema de Información Económica: Balanza Comercial de Mercancías de México. Available online: https://www.banxico.org.mx/SieInternet/consultarDirectorioInternetAction.do?sector=1\&idCuadro= CE125\&accion $=$ consultarCuadro\&locale $=$ es (accessed on 25 February 2020).

44. Calva, J. La economía mexicana en perspectiva. Econ. UNAM 2004, 1, 63-85.

45. Comisión Económica Para América Latina y el Caribe: Perspectivas económicas de México. 2019. Available online: https:/www.cepal.org/es/notas/perspectivas-economicas-mexico-2019 (accessed on 25 February 2020).

46. Heras, M.V.; Gómez, C.C. Exportaciones en México: Un análisis de cointegración y causalidad (1980-2012). Norteamérica 2015, 10, 103-131.

47. El Universal: Transnacionales Concentran un Tercio de las Exportaciones. Available online: https://www.eluniversal.com.mx/articulo/cartera/economia/2017/01/18/trasnacionales-concentranun-tercio-de-exportaciones (accessed on 25 February 2020).

48. Calva, J.L. Ajuste estructural y TLCAN. El Cotid. 2004, 19, 14-22.

49. Merino, L.; Velázquez, A. Agenda Ambiental 2018: Diagnóstico y Propuestas; Grupo Infragón: Ciudad de México, Mexico, 2018.

50. Consejo Nacional de Población: Ingresos Por Divisas a México Por Remesas Familiares, 1990-2018. Available online: http://www.conapo.gob.mx/work/models/OMI/NumeraliaMigratoria/2019/7/Graficos/Ingresos_por_ divisas_a_Mexico_segun_fuente,_1990-2018.html (accessed on 25 February 2020).

51. Hall, C.A.; Leon, C.; Ravenscroft, W.; Wang, H. Temporal and Spatial Overview of Costa Rican Agricultural Production. In Quantifying Sustainable Development: The Future of Tropical Economies, 1st ed.; Hall, C.A., Leon, P.C., Leclerc, G., Eds.; Academic Press: San Diego, CA, USA, 2000.

52. Expansion: 7 Empresas Mexicanas Que se Expanden en el Extranjero. Available online: https: //expansion.mx/negocios/2015/07/06/7-empresas-mexicanas-que-se-expanden-en-el-extranjero (accessed on 25 February 2020).

53. Grupo Mundo Ejecutivo: Las 100 exportadoras más importantes de México. Available online: http: //mundoejecutivo.com.mx/rankings/2015/06/25/100-exportadoras-mas-importantes-mexico/ (accessed on 25 February 2020).

54. Indigo: Maquila, Industria Dividida. Available online: https://www.reporteindigo.com/ indigonomics/maquila-industria-dividida-criticas-condiciones-laborales-desigualdad-economia/ (accessed on 25 February 2020). 
55. Malkin, E. A Slow-Motion Chernobyl: How Lax Laws Turned a River into a Disaster. Available online: https: //www.nytimes.com/2019/12/30/world/americas/mexico-environment-trade.html (accessed on 25 February 2020).

56. El Turismo Neoliberal en México. Available online: http://www.rebelion.org/noticias/2019/5/256224.pdf (accessed on 25 February 2020).

57. Durand, L. ¿Todos ganan? Neoliberalismo, naturaleza y conservación en México. Sociológica 2014, 82, 183-223.

58. Asociación Interamericana Para la Defensa del Ambiente AIDA. La Protección de los Arrecifes de Coral en México: Rescatando la Biodiversidad Marina y sus Beneficios Para la Humanidad. Available online: https://www.aida-americas.org/sites/default/files/featured_pubs/informe_corales_mexico.pdf (accessed on 25 February 2020).

59. Varela, L.R.; Ocegueda, H.J.; Castillo, P.R. Migración interna en México y causas de su movilidad. Perf. Latinoam. 2015, 25, 141-167. [CrossRef]

60. CEPAL: El Crecimiento Urbano y Las Violencias en México. Available online: http://adivac.org/pdf/ crecimiento-urbano-violencia.pdf (accessed on 25 February 2020).

61. Comisión Nacional de Hidrocarburos. Reservas de Hidrocarburos en México. Available online: https: //www.gob.mx/cms/uploads/attachment/file/435679/20190207._CNH-_Reservas-2018._vf._V7.pdf (accessed on 25 February 2020).

62. Base de Datos Institucional, PEMEX. Available online: https:/datos.gob.mx/busca/dataset/volumendel-comercio-exterior-de-productos-petroliferos-y-gas-licuado-de-petroleos-mexicanos (accessed on 25 February 2020).

63. El Economista: Precio de la Gasolina Escaló a Máximo Histórico en Marzo. Available online: https://www.eleconomista.com.mx/empresas/Precio-de-la-gasolina-escalo-a-maximo-historico-enmarzo-20190416-0026.html (accessed on 25 February 2020).

64. CEIC Data. Mexico Crude Oil: Production. Available online: https://www.ceicdata.com/datapage/en/ indicator/mexico/crude-oil-production (accessed on 25 February 2020).

65. El Financiero: Meta de Crecimiento Promedio de 4\% en Sexenio de AMLO se Queda Corta, Según Paquete Económico. 2020. Available online: https://elfinanciero.com.mx/economia/meta-de-crecimiento-de-4-ensexenio-de-amlo-se-queda-corta-en-paquete-economico-2020 (accessed on 25 February 2020).

66. Comisión Federal de Competencia Económica. Transición Hacia Mercados Competidos de Energía: Gasolinas y Diésel, 1st ed.; COFECE: Ciudad de México, Mexico, 2019.

67. Capra, F. La Trama de la Vida; Anagrama: Barcelona, España, 1998. 